\title{
VÁLASZ \\ Dr. Bartke István, Dr. Török Ádám és Dr. Varga Attila bírálók kérdéseire, megjegyzéseire
}

\section{LENGYEL IMRE}

Tisztelt opponenseim szerteágazó, sokszor egybecsengő, de időnként egymással is vitatkozó kérdéseit, megjegyzéseit, kritikai észrevételeit négy csoportba osztva igyekszem megválaszolni.

- Az első csoportba azok a kérdések és észrevételek kerültek, amelyek a témakör feldolgozásával és a dolgozat szerkezeti felépítésével kapcsolatosak.

- A második csoportba a globalizációs folyamatokról, a tudásalapú gazdaságban formálódó regionális specializációról, a kompetitív regionális fejlödésről vallott véleményemre tett megjegyzések tartoznak.

- A harmadik csoportba a regionális gazdaságtan megítéléséröl, a közgazdaságtudomány és az üzleti tudományok kapcsolatáról alkotott felfogásomhoz füzött észrevételeket soroltam.

- És végül, a negyedik csoport a területi verseny jellemzöihez, a regionális versenyképesség általam vallott felfogásához, piramis-modelljéhez, a masztabákhoz, a regionális versenyképesség empirikus hazai vizsgálatához kapcsolódó észrevételeket tartalmazza.

Elöre jelzem, hogy az opponenseim bírálatában foglaltakat megismerve azok jelentős részét olyan észrevételeknek tartom, amelyek pozitívan járulnak hozzá a témakörben végzett kutatásaim folytatásához és tudományos eredményeim továbbgondolásához. Elsősorban a bírálatokban leírt olyan észrevételekre és megjegyzésekre reagálok, amelyekkel vitatkozva pontosítom megállapításaimat és alátámasztom az értekezésben foglaltakat.

\section{1) A témakör fontossága és a dolgozat szerkezeti felépitése}

A kutatás témakörének aktualitását bírálóim egyhangúlag elismerik: napjainkban a versenyképesség regionális dimenzióinak vizsgálata kiemelt fontosságú problémakör, mind külföldön, mind itthon egyre több tudományos kutatás foglalkozik vele. Bírálóim szintén egyöntetüen kiemelik a dolgozat világos szerkezetét, a három fejezet logikus egymásra épülését. De azt is hozzáfüzik, hogy bizonyos belsö szerkezeti aránytalanságok is megfigyelhetök.

Török Ádám megjegyzi, hogy az elsö rész elsősorban leíró jellegủ, a szakterület néhány fontosabb általános eredményét mutatja be és a tudományos eredmények az 
értekezés második kétharmadára koncentrálódnak. Bírálóm ezen megállapítását elfogadva megjegyzem, hogy a szakma általánosan elfogadott eredményeit nemcsak ismertetem, hanem bizonyos pontokban kísérletet tettem továbbfejlesztésükre is. Elismerem, hogy valóban nem válik el markánsan a szakirodalom alapvető eredményeinek szintetizálása az én részeredményeimtöl, jobban ki kellett volna hangsúlyoznom saját hozzájárulásomat. Ilyennek tekinthető a regionális specializáció újjászervezỏdésének tárgyalása, a tárgyi alapú és a tudásalapú gazdaság összevetése, és ezek alapján a neofordista, átmeneti és tudásteremtỏ régiók típusainak elhatárolása, amelyek hosszas kutatómunkámon alapuló új eredmények. De többek között Alfred Marshall lokalizációs gondolatait összefoglaló és aktualizáló ábra jelenlegi ismereteim szerint újdonság, avagy a kompetitív regionális gazdaságfejlesztési stratégia adaptálása és kiegészítése is, amint azt Varga Attila bírálóm is elismeri.

A disszertációban a túl széles elméleti és gyakorlati hátteret emeli ki Bartke István is, hiányolva a régiók és megyék versenyképességének részletesebb elemzését. Magyarázatként talán tanulságos megemlítenem, hogy a dolgozat elsỏ változatában csak rövid elméleti háttér szerepelt, föleg az alkalmazott fogalmak bevezetése történt, illetve részletesen tárgyaltam az egyes régiók gazdasági helyzetét, különösen a Dél-alföldi régióban elvégzett kutatásainkat felhasználva. A dolgozat megvitatása során viszont az derült ki, hogy még a szükebb szakmán belül is „elbeszélünk egymás mellett". Nemcsak mást értünk a globalizáció teruileti hatásain, a térbeli koncentráció közgazdasági jellemzőin, a területi versenyen stb., de sokszor még az alapfogalmakat is eltérỏen értelmezzük, illetve felületesen ismerjük a legújabb mérvadó nemzetközi eredményeket. A fogalmak és alapgondolatok eltérő értelmezései arra is utalnak, hogy napjaink új térszerveződésére nincsenek még nagyjából egységesen elfogadott magyarázatok. Egy dinamikusan bővülö, interdiszciplináris témakörben ez a sokszínüség érthetö, de nem járhat együtt felszínességgel, ezért szintetizáltam napjaink legújabb eredményeit, amelyekre a régiók versenyképességének vizsgálatát alapoztam.

A szintetizálás során végig kellett gondolnom a témakör legfontosabb irányzatainak gondolatait, fogalmait és eredményeit. Ez szakmailag nagyon izgalmas kutatás, időigényes irodalmazás volt, a tudásom és dioptriáim száma gyarapodott, miközben próbáltam áttekinteni és megérteni a különböző irányzatokat. A dolgozatban a mondanivaló súlypontja is értelemszerüen eltolódott, valószínúleg emiatt a címet is némileg módosítanom kellett volna, elhagyva belőle a Magyarország szót. Ezáltal helyreállt volna a cím és a tartalom teljes mértékü összhangja, amint annak hiányát Bartke István is megjegyzi.

Bírálóim hiányolják az eredményeket összegző fejezetet. Valóban, ilyen elkülönült fejezet nincs a disszertációban, mivel másik megoldást választottam: fejezetenként foglalom össze megállapításaimat. Talán szerencsésebb lett volna, vigyázva a túlzott mértékú ismétlésekre, ha külön fejezetben összefoglalom eredményeimet és mondanivalómat, pl. a tézisekhez hasonlóan. 


\section{2) Globalizációs folyamatok, tudásalapú gazdaság és regionális specializáció}

A régiók versenyképességének vizsgálatához a régiók fogalmán túl azt is tisztáznunk kell, mit értünk területi verseny alatt és milyen jellemzőkkel írható le. Felfogásom szerint régiók közötti területi versenyről csak az 1990-es évek elejétỏl beszélhetünk, a globalizációs folyamatok főbb dimenziói, a dereguláció kibontakozása, az infokommunikációs technológiák elterjedése és a szállítási költségek csökkenése, azaz a globális verseny megerősödését követően. A korábbi időszakokban inkább rivalizálás, versengés folyt, nem pedig nagyjából kiszámítható feltételek között zajló területi verseny. A korszakhatár meghúzása miatt nem dolgoztam fel részletesen a korábbi időszak külföldi és hazai eredményeit, így kimaradtak nemcsak a saját korábbi munkáim, de a Bartke István által jelzett, más munkáimban általam is meghivatkozott kiváló tanulmányok.

A globalizációs folyamatokat többféleképp lehet rendszerezni, a vállalati versenyelőnyök szempontjából Michael Porter eredményeit jól értelmezhetőnek tartom. Az ó globális-lokális paradoxonát bővítettem ki a dolgozat témaköre, a globális verseny, versenyképesség és regionális specializáció szempontjából. Varga Attila ezt a paradoxont és összegző ábrát a gazdaság új térbeli folyamatai jó leírásaként fogadja el, míg Bartke István vitatja. Jómagam ezt a paradoxont meghatározónak tartom, az iparági tartós versenyelónyökkel foglalkozó számos vizsgálat igazolta. Megjegyzem, hogy a globálisan ható folyamat egyes tényezői nem vethetők össze páronként a lokális folyamat tényezőivel, hanem a két folyamatot komplexen lehet csak összehasonlítani.

A disszertáció első négy fejezete szintézisének tartom a tudásalapú gazdaságban újraszerveződő regionális specializációt, amit Varga Attila is megerősít, és további kutatások során finomítani szeretném ezen három régió-típus értelmezését. Török Ádámnak abban igaza van, hogy a „tudásalapú gazdaság” kifejezés nem jó, csak egy szó szerinti fordítás, amelyik nem fedi a fogalom lényegét. Hasonlóan gondot okozott a „tradeable, traded” szektor megnevezése is. Sajnos nem tudok jobbat, szívesen partner vagyok a tartalmat megfelelö módon kifejező szakmai kifejezések megtalálásában. Mint egyetemi oktató megjegyzem, hogy csak akkor lesz sikeres a szó szerinti fordítástól eltérő, de tartalmilag korrekt kifejezés elterjesztése, ha az ezzel foglalkozók egységesen ezt alkalmazzák publikációikban és tankönyveikben, föleg a bevezetó egyetemi kurzusok tananyagaiban.

Mint említettem, a régiók típusait a regionális gazdaságfejlesztés szempontjai alapján kủlönítettem el, mivel eltérő módon versenyeznek és versenyképességük javítása is másféle eszközökkel eredményes. Elfogadom Bartke István észrevételét, hogy a három régió-típus között nem vertikális a viszony. A disszertáció elkészülte óta végzett további kutatások eredményei alapján egyrészt az átmeneti régió helyett a ,tudásalkalmazó régió” kifejezést használjuk, másrészt elfogadjuk, hogy a gazdasági kibocsátást (GDP/lakos) tekintve egyaránt fejlett lehet a tudásalkalmazó és a 
tudásteremtő régió is. Másképpen, nem lesz mindegyik régió tudásteremtő, enélkül is lehet magas ott az életszínvonal. Az EU-ban a Harmadik Kohéziós Jelentéshez a régiók versenyképességéről 2003-ban, a disszertációm leadása után készült, nagy adatbázist alkalmazó ökonometriai vizsgálat eredményei lényegében megegyeznek az általam adott, a szakirodalmon és hazai vizsgálatokon alapuló tipizálással: termelô régiók (nálam neofordisták), növekvő skálahozadékú régiók (tudásalkalmazók) és tudásközpont régiók (tudásteremtők). Azaz úgy érzem, hogy a matematikaistatisztikai vizsgálatok megerősítették a tipizálásomat, emiatt a magyar régiók és megyék versenyképességének elemzésére és a fejlesztési stratégiák kidolgozására az egyes típusok masztabáinál az általam megadott jellemzőket figyelembe lehet venni.

Török Ádám jogosan jegyzi meg, hogy a rurális régiók hiányoznak ebből a felsorolásból. Valóban, tudatosan kihagytam öket, mivel nem vesznek részt érdemben a területi versenyben. Nagyon fontos ezen régiók fejlődésének elősegítése, de ez nem a piaci folyamatoktól, hanem közösségi beavatkozásoktól várható el. Megjegyzem, hogy az országok versenyképességével foglalkozó vizsgálatok sem terjednek ki mindegyik országra, hanem csak a fejlettebbekre, a Világgazdasági Fórum tavaly 80 , az IMD 51 országot (és 8 régiót) hasonlított össze, amiben nyilván az adatgyüjtés problémái is szerepet játszottak.

Varga Attila felvetése is jogos, a szellemi tevékenységek kiszervezése elindulásának a kilencvenes évek kỏzepét jelöltem meg, pedig már pl. a Szilícium-völgyben korábban is megfigyelhetö volt. Nyilván én a tömeges kiszervezésekre gondoltam, nemcsak az USA-ban lezajlott akciókra, amelyekhez az Internet széles körü elterjedése nélkülözhetetlen.

\section{3) A regionális gazdaságtan és a közgazdaságtudomány kapcsolatáról}

A verseny és versenyképesség eltérỏ megítélés alá esik az elméleti közgazdaságtudományban, valamint a gazdálkodástanban (üzleti tudományokban). Ez az eltérỏ megítélés részben az egyes diszciplínák jellegéből adódik, illetve a versenyképesség megitéléséböl. Török Ádám többször kifejtette publikációiban, hogy a neoklasszikus közgazdaságtan gondolatrendszere és alapkategóriái alapján a versenyképesség nem értelmezhetö. Részben emiatt az általam alkalmazott egységes versenyképesség fogalmának mérése inkább a gazdasági növekedéselméletek gondolataihoz áll közel. Viszont a "versenyre való képesség”, a versenyképesség javítása már a gazdaságpolitika, gazdálkodástan szemléletét és eszközeit igényli. Tehát a versenyképesség vizsgálata két elkülönülő irányzatra vezethető vissza, ami maga után vonja az eltérỏ fogalomrendszerek használatát, ezáltal azok bizonyos keveredését is. Elfogadom Bartke Isván és Varga Attila ez irányú észrevételeit, több helyen nem különül el teljesen egyértelmüen, hogy közgazdaságtudományi, avagy gazdaságpolitikai megközelítésról van-e szó.

A kompetitiv fejlődés Porter-féle megközelítése a komparatív elönyök bizonyos szempontú kiegészítésére, meghaladására törekszik. Török Ádámmal egyetértek, Porter gazdaságelméleti gondolatai eléggé elnagyoltak és pontatlanok, hiszen ő 
inkább gazdaságpolitikai „magyarázatként” használja fel a komparatív előnyökkel történö összevetést, a gazdaságfejlesztési stratégiák kidolgozásához viszont a gyakorlatban jól alkalmazhatók a felvetései, így a verseny új dimenzióival kapcsolatos szemléltető jellegủ meglátásai. A komparatív előnyökre épülő munkamegosztás országok esetében általánosan elfogadott, viszont országon belüli szubnacionális régióknál a tényezóellátottság nem adott, a munkaerő ingázhat a régiók között stb. A témakör regionális szakirodalmában 2002 után több olyan tanulmány megjelent, amelyik a régiók közötti versenyben az abszolút elönyöket, azaz a kompetitív elönyöket hangsúlyozza. Ez a nemzetközileg is új kérdéskör a disszertációnak csak egyik mellékkérdése, de megérdemel egy alaposabb kutatást, és ha erre időt tudok szánni, mindenképpen igénybe veszem Török Ádám felajánlott szakmai segítségét.

A térgazdaságtan legfontosabb alapgondolatainak összehasonlító szemléltetésénél a regionális gazdaságtan és a nemzetközi gazdaságtan ,ideáltípusait”, azaz leegyszerüsített felfogásukat ismertettem, amelyek túlzott egyoldalúságát Török Ádám és Varga Attila is szóvá tette. Amint a rövid szöveges elemzésböl kiderül, fö célom nem a három elmélet alapos összevetése volt, hanem Krugman felfogásának szemléltetése, ezért használtam csak az ő munkáit térgazdaságtana néhány jellegzetességének bemutatására.

Bartke István vitatja azt a kijelentésemet, hogy a „közgazdaságtudományban a 90-es évekig föleg a mikro- és makroszint ... voltak a vizsgálatok alapegységei, a kettő közötti mezoszintre, így a regionális és városi szintre alig fordítottak figyelmet". Azzal egyetértek, hogy a regionális gazdaságtanban is kiváló elemzések születtek, külföldön és itthon is. De ennek ellenére véleményem szerint sajnos helytálló, hogy ezek az ismeretek nem tartoznak a közgazdászok alapmúveltségébe, a regionális gazdaságtan eredményei nem kerültek méltó helyükre, Varga Attilával egyetértve, kimaradtak a fövonalból. Ezt én is nagyon sajnálom, mint a regionális gazdaságtan tárgyának oktatója és a témakör müvelöje, de pl. végignézve a hazai közgazdasági felsöoktatás tankönyveit: a mikroökonómia, vállalatgazdaságtan, marketing stb. könyvekböl szinte teljesen hiányzik a tér és távolság gazdasági szempontú felvetése. A gazdaságföldrajz is egyre kevesebb helyen szerepel a közgazdasági képzésekben, általában csak választható tárgy lett belöle. Kivételnek számít a Pécsi Tudományegyetem, illetve Miskolc, Györ és Szeged, ahol a közgazdasági képzésben továbbra is vannak regionalista tárgyak. Azaz úgy kapnak tömegesen diplomát a fiatal közgazdászok, nemcsak a föiskolákon, hogy a közgazdaságtudomány alatt csak mikro- és makroökonómiát értenek, egyetemeken esetleg még a nemzetközi gazdaságtant is. A közeljövőben megjelenő, Rechnitzer Jánossal közösen írt ,regionális gazdaságtan" címü monográfiảnkban áttekintjük az alapvetö eredményeket, de csak remélni tudjuk, hogy a közgazdászok kézbe is veszik majd ezt a munkát. (A kötet 2004 decemberében a Dialóg Campus Kiadó gondozásában megjelent - a szerk.) Több egyetemen, többek között Györben és Szegeden is a szervezödő üzleti alapszakok tanrendjében már szerepel a regionális gazdaságtan, amelynek alapkönyve lesz ez a monográfia. 
Varga Attila nem ért velem egyet, hogy a „regionális gazdaságtan nem használta a kôzgazdaságtanban elterjedt mikro- és makroökonómiai nyelvezetet". Valóban, ezt a sarkos megállapításomat pontosítanom kell, mivel a regionális gazdaságtan címmel megjelenő munkák nagyjából két nagyobb csoportra oszthatók. Az egyik csoport, közte Hoover, Isard, Alonso, Henderson stb. bevezette és használta a határelemzés fogalmait (határköltség, határhaszon stb.), az aggregált keresleti és kínálati függvényeket, termelési függvényeket, a lokális extern hatásokat, az általános egyensúlyhoz kapcsolódó gondolatokat, a térbeli piacszerkezeteket stb. A másik csoport inkább területi statisztikai, avagy gazdaságföldrajzi fogalmakból kiindulva magyarázza a gazdasági folyamatok térbeliségét. Az említett, Rechnitzer Jánossal közösen írt monográfiánkban az elméleti közgazdaságtudomány fogalmaira építve vázoljuk a regionális gazdaságtant. A nevezéktani megjegyzésekhez kapcsolódik, hogy Varga Attila szerint a Krugman-féle irányzatnál a „térgazdaságtan" helyett más elnevezést kellene használni. Valóban, ezen sokat meditáltunk, de ha jól emlékszem, éppen az általa Pécsett tartott kurzus neve miatt maradtam a térgazdaságtan mellett, persze tudva azt, hogy ő általánosabb értelemben, lényegében a modern regionális gazdaságtan szinonímájaként használja, amelyen belül csak egy irányzat az „új gazdaságföldrajz”.

\section{4) Területi verseny, versenyképesség és piramis-modell}

Bírálóim megállapítják, hogy a dolgozat meggyőzően bizonyítja, az egyes területek között is kialakul a verseny, valamint meghatározza a régiók közötti verseny jellemzöit. A jelentős új eredmények közé sorolják a nemzetközi forrásmunkák elemzỏ áttekintésével a regionális versenyképesség fogalmának, értelmezésének bemutatását, valamint a magyar megyék versenyképességének meghatározását. Kiemelik, hogy a disszertációban szereplö regionális versenyképességi vizsgálatok nemcsak a magyar, hanem a nemzetközi szakirodalomban is új, vagy újszerü eredményeket mutatnak be.

Magam is a dolgozat egyik fontos eredményének tartom a piramis-modellt, és Török Ádámmal egyetértve, ez a modell valóban egy demonstrációs séma és az egzaktabb regionális növekedési modellek keveréke. A piramis-modell a regionális fejlödés és gazdaságfejlesztés logikai keretét írja le: célként megfogalmazva az átlagos életszínvonalat, eszközként definiálva a versenyképesség javulását, amelyet rövid távon bizonyos alaptényezők befolyásolnak, míg hosszabb távon sikerességi faktorok. Mint kutatónak nagy öröm, hogy többen meghivatkozták ezzel kapcsolatos publikációmat (eddig 41 általam ismert független hivatkozás történt), több tankönyvben is átvették, illetve Cambridge-ben már 3 szemináriumi előadáson felhasználták (igaz, hogy hivatkozás nélkül, azaz „ellopták”, de reklamálásomra pótolták a hivatkozást).

A piramis-modell egy általános elvi keret, amely elsősorban az alapkategóriákkal méri a versenyképességet, míg az alaptényezők fejlesztésére a régiók típusától függỏen más-más eszközöket kell alkalmazni. Ezeket az eszközöket rendszerezik a 
„masztabák”. Török Ádámnak igaza van, ez egy szokatlan kifejezés, de nekem a piramis-modellről mindig az egyiptomi piramisok jutnak eszembe, amelyek körül ott találhatók a fáraó rokonainak, fontosabb szolgáinak kisebb kögúlái, azaz „masztabái”. Ezáltal a kifejezés jelzi ezen modelleknek a piramis-modellel való alárendelt viszonyát is.

A magyar megyék versenyképességét a piramis-modell alapján, 35 mutatót figyelembe véve, egy összemérési módszer alapján adtam meg. Ezek a mutatók az alapkategóriák, illetve alaptényezők szerint lettek kiválasztva, emiatt nem szerepelt több, egyébként fontos mutató, mint a gazdasági szerkezet, a lakosság iskolai végzettsége stb. A rendelkezésemre álló statisztikai adatok alapján ez egy kísérlet volt a piramis-modell verifikálására. Bartke István megjegyzi, hogy a nagy nevü egyetemekkel rendelkező megyék háttérbe kerültek a versenyképességi rangsorban. Az adatok alapján ez számomra egyértelmü, mivel ezen vidéki egyetemek többsége, közte a Szegedi Tudományegyetem, nem a vállalati szféra számára képez szakembereket és gyenge a kapcsolata a helyi gazdasági szférával, azaz a Dél-alföldi régió tipikus neofordista régió.

Nagyon lényeges kérdés, milyen fejlesztési stratégiával lehet az egyik régió típusból átkerülni egy másikba, mely kérdésre a masztabák nem adnak választ. A kompetitív regionális gazdaságfejlesztési stratégia tartalmazza azokat a gazdaságpolitikai és területfejlesztési eszközöket, amelyek segítségével elérhető ez az ,átbillenés". Azaz Török Ádám kérdésére válaszolva, emiatt jelenik meg a dolgozat végén újra Porter szakaszos fejlődési modellje.

Az értekezésemben kidolgozott témakör napjainkban is ,forrong”, a fogalmak és gondolatok még nem tisztázódtak le, emiatt utólag rájöttem, hogy igen nehéz témakört választottam. A nehézséget fokozta, hogy a témakör elméleti kérdései mellett mindvégig arra törekedtem, hogy a regionális versenyképesség javításának gyakorlati szempontjait is megértsem. Azaz ne csak magyarázzam a versenyképességet, hanem javaslatokat is tudjak kidolgozni a régiók versenyképességének növelésére. Egy nemzetközileg is új témakörnél idő kell, amíg a fogalmak, gondolatok lecsiszolódnak, a régiók versenyképességének vizsgálatánál ez még nem történt meg, amint a bírálatokból is kiderül.

Végezetül szeretnék köszönetet mondani bírálóimnak, hogy hasznos megjegyzéseikkel, kritikai észrevételeikkel segítették dilemmáim megoldását, vagy megerősítették elképzeléseim megalapozottságát, vagy felhívták figyelmemet a tisztázandó kérdésekre, és így hozzájárultak egyes gondolataim pontosabb kifejtéséhez.

Szeged, 2004. október 20. 